\title{
Optimalisasi Pemanfaatan Lahan Marginal Kering untuk Budidaya Padi Gogo di Riau
}

\author{
Idwar*, Anthony Hamzah, Besri Nasrul \\ Jurusan Agroteknologi, Fakultas Pertanian, Universitas Riau \\ * idwarmansyur@yahoo.co.id
}

\begin{abstract}
Abstrak. Ketersediaan lahan untuk usaha pertanian merupakan syarat mutlak untuk mewujudkan swasembada, ketahanan, mandirian, dan kedaulatan pangan nasional. Lahan marginal kering berpotensi mendukung peningkatan produksi padi nasional. Keberadaannya menjadi solusi optimalisasi lahan kering sebagai pengganti lahan sawah yang terkonversi. Upaya menggalakkan budidaya padi gogo berpeluang besar dalam peningkatan produksi padi di Riau karena telah dibudidayakan masyarakat secara turun temurun. Budidaya padi gogo di Provinsi Riau umumnya diusahakan pada lahan marginal kering (Inceptisol, Ultisol), yang kendala utamanya adalah ketersedian air yang terbatas, kesuburan tanah rendah (terutama P terikat kuat oleh aluminium sehingga tidak tersedia), dan bahan organik rendah. Berbagai penelitian yang andal pada beberapa kondisi ketersedian air, penggunaan varietas ungggul dan dengan menerapkan teknologi tepat guna berupa pemberian bahan amelioran telah dapat mengoptimalkan pemanfaatan lahan marginal kering dan meningkatkan produktifitasnya. Selanjutnya untuk keberlangsungan budidaya padi gogo di lahan marginal kering tergantung pada konsistennya pemerintah pusat maupun daerah dalam menerapkan UU Nomor 41 Tahun 2009 tentang Perlindungan Lahan Pertanian Pangan Berkelanjutan.
\end{abstract}

Kata Kunci: optimalisasi, lahan marginal kering, budidaya, padi gogo, amelioran, produktifitas, varietas unggul, pertanian pangan berkelanjutan

\section{PENDAHULUAN}

Tanaman padi merupakan salah satu komoditas tanaman pangan nasional yang harus diupayakan ketersediaannya tercukupi sepanjang tahun. Kebutuhan yang selalu meningkat atas bahan pangan beras perlu diimbangi dengan perluasan areal pertanian dan pengusahaan pengelolaan lahan yang lebih intensif. Usahausaha ini termasuk pengelolaan lahan marginal untuk lahan pertanian pangan, terutama padi gogo agar kesenjangan antara kebutuhan dan produksi beras tidak semakin melebar.

Budidaya padi gogo di lahan kering berpotensi untuk mendukung peningkatan produksi padi nasional, Perkembangan luas tanam padi gogo di kabupaten-kabupaten melalui program-program ekstensifikasi maupun intensifikasi untuk mengantisipasi kekurangan pangan di Provinsi Riau belum optimal ( \pm 25.335 ha), padahal potensi lahan kering yang tersedia cukup luas 306.507 ha, dengan sentra pertanamannya adalah Kabupaten Rokan Hulu, Kuantan Singingi dan Kampar. Dinas Tanaman pangan dan Hortikultura (2011) melaporkan bahwa produksi padi gogo di Provinsi Riau tahun 2010 sebesar 67.494 ton/tahun, dengan tingkat produktivitas 2,72 ton/ha, dan kontribusi produksi padi gogo baru mencapai $5-6 \%$.

Lahan-lahan marginal kering yang ditanami padi gogo ini sebahagian besar adalah jenis tanah Ultisol dan Inceptisol yang memiliki daya pegang air yang rendah sehingga ketergantungan pada intensitas, distribusi curah hujan dan jumlah hari hujan sangat tinggi. Ketersedian air dalam tanah sangat menentukan keberhasilan budidaya padi gogo di lahan kering. Namun yang perlu menjadi perhatian adalah waktu tanam, dimana merupakan masalah pada keadaan tadah hujan karena keragaman dari awal musim.

Berbagai upaya perbaikan dan peningkatan budidaya padi gogo telah dilakukan pada tanah marginal (suboptimal) kering, ternyata tanaman padi gogo berpeluang ditingkatkan produktifitasnya melalui adopsi varietas unggul dan perbaikan teknik budidaya. Menurut Hakim (2014), penggunaan varietas unggul dapat menjadi teknologi paling murah dan efisien untuk meningkatkan produktifitas padi lahan kering, Seleksi padi gogo varietas unggul sangat berguna untuk mendapatkan varietas adaptif pada kondisi marginal. Sedangkan teknologi untuk membenahi permasalahan lahan marginal kering, menurut Soepardi (1990), ada 3 pilihan dasar, yaitu pemberian kapur (CaCO3); bahan organik; dan batuan fosfat alam (BFA). Dari tiga pilihan dasar

To cite this article: Idwar., A. Hamzah., dan B. Nasrul. 2019. Optimalisasi Pemanfaatan Lahan Marginal Kering untuk Budidaya Padi Gogo di Riau. Unri Conference Series: Agriculture and Food Security 1: 190-198. https://doi.org/10.31258/unricsagr.1a25 
diramu menjadi beberapa kombinasi tindakan. Dengan upaya ameliorasi ini, lahan marginal kering mencapai kesiapan menuju ke produktif. Memanfaatkan dan merawat adalah kiat kesuksesan mengelola lahan marginal kering.

Namun semua upaya di atas tidak banyak berarti apabila pemerintah pusat maupun daerah tidak konsisten dalam menerapkan UU Nomor 41 Tahun 2009 tentang Perlindungan Lahan Pertanian Pangan Berkelanjutan. Penerapan UU tersebut merupakan upaya pengamanan tanah (soil security) dan merupakan kunci untuk meningkatkan produktifitas tanah dan upaya pengoptimalan pemanfaatannya dalam mendukung pertanian pangan berkelanjutan di Daerah Riau.

\section{METODE}

Pewilayahan iklim merupakan tindak lanjut interpretasi yang sangat efektif untuk memanfaatkan iklim guna mengoptimalkan hasil produksi tanaman padi gogo. Klasifikasi berdasarkan Oldeman dan Las,1977 (dalam Badan Penelitian dan Pengembangan Provinsi Riau, 2012) menggunakan metode perimbangan antara curah hujan rata-rata bulanan dengan evapotranspirasi potensial dalam menduga musim tanam (growing season) dan atau ketersedian air pada suatu wilayah sangat membantu dalam menentukan jumlah ketersediaan air dan kebutuhan tanaman padi gogo. Dalam klasifikasi Oldeman ditetapkan pula batas terendah curah hujan untuk padi gogo dan palawija adalah $>100 \mathrm{~mm} /$ bulan. Bulan dengan curah hujan $<100 \mathrm{~mm} / \mathrm{bulan}$ disebut bulan kering.

\section{HASIL DAN PEMBAHASAN}

\section{Geografis, Iklim dan Jenis-Jenis Tanah Berpotensi Untuk budidaya Padi Gogo di Provinsi Riau}

Provinsi Riau dengan luas wilayah daratan \pm 8.915 .016 Ha terletak antara $01^{\circ} 05^{\prime}$ LS $-02^{\circ} 25^{\prime}$ LU dan antara $100^{\circ} 00^{\prime}-105^{\circ} 05^{\prime}$ BT. Berdasarkan letak administratif, batas-batas sebelah Utara dengan Selat Malaka dan Provinsi Sumatera Utara, sebelah Selatan dengan Provinsi Jambi dan Sumatera Barat, sebelah Timur dengan Provinsi Kepulauan Riau dan Selat Malaka, dan sebelah Barat dengan Provinsi Sumatera Barat dan Sumatera Utara.

Kondisi tanah di wilayah daratan Riau secara umum didominasi oleh jenis tanah Organosol (Histosol), Podsolik Merah Kuning (Ultisol), Gley Humus (Entisol), dan lain-lain. Luas tanah Histosol dan Entisol mencapai 5.065.600 Ha, Ultisol mencapai 2.156.000 Ha, sisanya jenis-jenis tanah lain. Wilayah Provinsi Riau sebagian besar lahannya terhampar di daerah datar/cekungan dengan jenis tanahnya gambut (Histosol), tanah Sulfat Masam potensial (Entisol), Aluvial (Inceptisol) dan regosol (Entisol), sedang di daerah bergelombang sampai berbukit didominasi tanah Ultisol, dan sedikit tanah Podzol (Spodosol) dan lateritik (Oxisol) (Badan Penelitian dan Pengembangan Provinsi Riau, 2012). Tanah-tanah ini tergolong marginal dan dapat dikatakan tidak mampu berproduksi secara optimal jika dikelola secara konvensional. Sebaran jenisjenis tanah yang ada di Provinsi Riau disajikan pada Gambar 1.

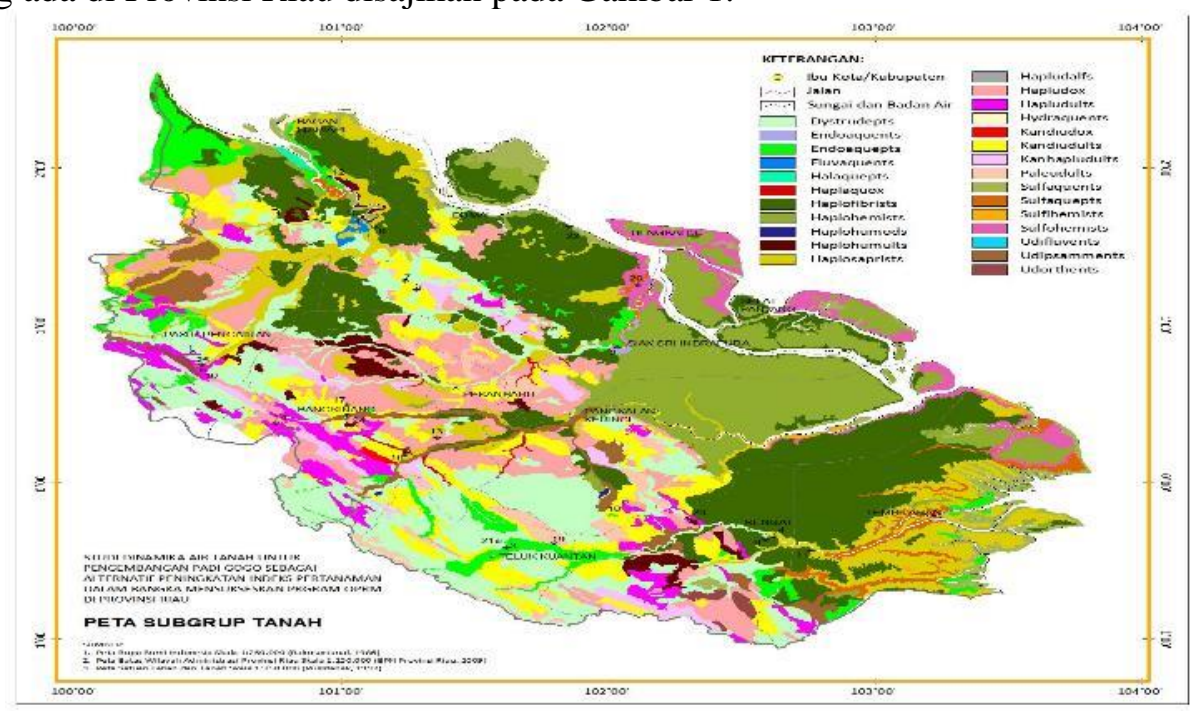

Gambar 1. Sebaran Jenis-Jenis Tanah di Provinsi Riau 
Provinsi Riau, memiliki potensi sumberdaya lahan kering cukup luas yang belum dimanfaatkan secara optimal dalam upaya ketahanan pangan. Potensi lahan kering di Riau \pm 1.158 .345 ha, telah dimanfaatkan 852.020 ha, dan peluang pengembangan 306.507 ha (Badan Pusat Statistik, 2006) . Untuk lebih jelasnya disajikan pada Tabel 1.

Tabel 1. Potensi, pemanfaatan dan peluang pengembangan lahan kering di provinsi riau tahun 2005

\begin{tabular}{llrrr}
\hline No & \multicolumn{1}{c}{ Kabupaten/Kota } & Potensi (Ha) & Pemanfaatan $(\mathrm{Ha})$ & Peluang Pengembangan (Ha) \\
\hline 1. & Kampar & 177.717 & 81.887 & 95.830 \\
2. & Indragiri Hulu & $95.516,5$ & $57.069,5$ & 38.447 \\
3. & Indragiri Hilir & 82.479 & 70.053 & 12.426 \\
4. & Bengkalis & 18.876 & 98.782 & 20.094 \\
5. & Pekanbaru & 7.301 & 2.193 & 5.108 \\
6. & Pelalawan & 110.777 & 47.648 & 63.129 \\
7. & Rokan Hulu & 191.590 & 157.838 & 33.752 \\
8. & Kuantan Singingi & 8.753 & $14.413,5$ \\
9. & Siak & $23.165,5$ & 234.944 & 17.699 \\
10 & Rokan Hilir & 252.463 & 92.057 & 4.988 \\
11 & Dumai & 97.045 & 795 & 620 \\
\hline & Jumlah & 1.415 & 853.020 & 306.507 \\
\hline
\end{tabular}

Lahan marginal kering sebagain besar telah dimanfaatkan sebagai areal perkebunan kelapa sawit. Ini menunjukkan bahwa potensi pemanfaatan lahan kering sangat besar. Lahan kering adalah hamparan lahan yang tidak pernah tergenang atau digenangi air pada sebagian besar waktu dalam setahun. Sebagian besar lahan kering bereaksi masam dengan jenis tanah Inceptisol dan Ultisol yang memiliki ciri-ciri kimia seperti disajikan pada Tabel 2 dan 3.

Tabel 2. Beberapa sifat kimia tanah Inceptisol yang digunakan dalam percobaan-percoban penelitian

\begin{tabular}{clcc}
\hline No & \multicolumn{1}{c}{ Jenis Analisis } & Hasil Analisis & Kriteria (PPT,1983) \\
\hline 1 & $\mathrm{pH}\left(\mathrm{H}_{2} \mathrm{O}\right)$ & 5,26 & Masam \\
2 & $\mathrm{pH}(\mathrm{KCl})$ & 4,90 & Masam \\
3 & C-Organik $(\%)$ & 2,38 & Sedang \\
4 & N-Total $(\%)$ & 0,26 & Sedang \\
5 & P-Tersedia $(\mathrm{ppm})$ & 27,18 & Tinggi \\
6 & $\mathrm{C} / \mathrm{N}$ & 9,15 & Rendah \\
7 & $\mathrm{~K}-\mathrm{dd}(\mathrm{cmol}(+) / \mathrm{kg})$ & 0,35 & Sedang \\
8 & $\mathrm{Mg}-\mathrm{dd}(\mathrm{cmol}(+) / \mathrm{kg})$ & 0,20 & Sangat rendah \\
9 & $\mathrm{Ca}-\mathrm{dd}(\mathrm{cmol}(+) / \mathrm{kg})$ & 1,54 & Sangat rendah \\
10 & Na-dd $(\mathrm{cmol}(+) / \mathrm{kg})$ & 1,37 & Sangat tinggi \\
11 & $\mathrm{Al}-\mathrm{dd}(\mathrm{cmol}(+) / \mathrm{kg})$ & 0,57 & Sangat rendah \\
12 & $\mathrm{H}-\mathrm{dd}(\mathrm{cmol}(+) / \mathrm{kg})$ & 2,16 & Sangat rendah \\
12 & $\mathrm{KTK}(\mathrm{cmol}(+) / \mathrm{kg})$ & 11,40 & Rendah \\
13 & Kejenuhan Basa $\%)$ & 30,35 & Rendah \\
14 & Kejenuhan Al $(\%)$ & 13,18 & Sedang \\
\hline
\end{tabular}

Hasil Analisis Laboratorium Minamas Plantation Teluk Siak, Riau, 2011

Tabel 3. Beberapa sifat kimia dan Fisik tanah Ultisol yang digunakan dalam percobaan-percobaan penelitian

\section{Sifat Kimia *)} Parameter Analisis

\author{
$\mathrm{pH}\left(\mathrm{H}_{2} \mathrm{O}\right)$ \\ C-organik \\ $\mathrm{N}$ Total \\ $\mathrm{C} / \mathrm{N}$
}

Kapasitas Tukar Kation
Hasil

$1,32 \%$

$0,11 \%$

12

$8,18 \mathrm{me} / 100 \mathrm{~g}$
Kriteria

Sangat masam

Rendah

Tinggi

Sangat rendah

Rendah 


\begin{tabular}{|c|c|c|}
\hline Parameter Analisis & Hasil & Kriteria \\
\hline $\mathrm{P}_{2} \mathrm{O}_{5} \mathrm{HCl} 25 \%$ & $21,99 \mathrm{mg} / 100 \mathrm{~g}$ & Sedang \\
\hline $\mathrm{K}_{2} \mathrm{O} \mathrm{HCl} 25 \%$ & $16,21 \mathrm{mg} / 100 \mathrm{~g}$ & Rendah \\
\hline $\mathrm{P}_{2} \mathrm{O}_{5}$ Bray I & $14,8 \mathrm{ppm}$ & Rendah \\
\hline Ca-dd & $0,121 \mathrm{me} / 100 \mathrm{~g}$ & Sangat rendah \\
\hline Mg-dd & $0,072 \mathrm{me} / 100 \mathrm{~g}$ & Sangat rendah \\
\hline K-dd & $0,013 \mathrm{me} / 100 \mathrm{~g}$ & Sangat rendah \\
\hline Na-dd & $0,00034 \mathrm{me} / 100 \mathrm{~g}$ & Sangat rendah \\
\hline Al-dd & 4,40 me Al-dd/100 g & - \\
\hline Kejenuhan Alumunium & $57,47 \%$ & Tinggi \\
\hline Kejenuhan Basa & $2,5 \%$ & Sangat rendah \\
\hline \multicolumn{3}{|l|}{ Sifat Fisik Tanah } \\
\hline Pasir & $52,02 \%$ & \\
\hline Debu & $14,95 \%$ & \\
\hline Liat & $33,03 \%$ & Lempung berpasir \\
\hline
\end{tabular}

Hasil Analisis Laboratorium Fakultas Pertanian Unri (2016)

Badan Penelitian dan Pengembangan Provinsi Riau (2012) melaporkan bahwa Riau memiliki iklim tropis basah dengan rata-rata curah hujan berkisar antara 1.324,5 - 3.538,6 mm/tahun yang dipengaruhi oleh musim kemarau dan musim hujan. Suhu udara relatif stabil, yaitu rata-rata sekitar 30,21oC dan maksimum 30,97oC. Kelembaban relatif pada semua bulan relatif tinggi yaitu 86,36 - 91,23\%, sebaliknya penyinaran matahari relatif rendah yaitu 46,0 - 63,5\% (BMG, 2000-2009).

Keragaman jumlah curah hujan dan hari hujan antara bulan-bulan musim penghujan dengan bulan-bulan musim kemarau tampak jelas antar kabupaten. Begitu juga awal jatuhnya bulan-bulan curah hujan terbanyak dan terendah juga berbeda-beda antar kabupaten. Adanya keragaman curah hujan dalam setahun pada masing-masing kabupaten menyebabkan hujan merupakan unsur iklim yang berpengaruh dominan terhadap produksi pertanian di Riau melalui ketersediaan air bagi tanaman. Selanjutnya rata-rata curah hujan dan hari hujan per bulan setiap kabupaten-kabupaten di Provinsi Riau disajikan pada Tabel 4.

Tabel 4. Rerata Curah Hujan dan Hari Hujan/Bulan di Kabupaten-kabupaten Provinsi Riau

\begin{tabular}{lccccccccccccc}
\hline \multirow{2}{*}{ Kabupaten } & \multicolumn{1}{c}{ Jan } & Feb & Mar & Apr & Mei & Jun & Jul & Agt & Sep & Okt & Nov & Des & Total \\
\hline Indragiri & 207 & 168 & 251 & 257 & 171 & 138 & 140 & 139 & 160 & 184 & 269 & 206 & 2290 \\
Hilir & $(12)$ & $(8)$ & $(12)$ & $(10)$ & $(10)$ & $(5)$ & $(7)$ & $(6)$ & $(8)$ & $(9)$ & $(11)$ & $(12)$ & $(110)$ \\
Indragiri & 241 & 173 & 263 & 297 & 196 & 128 & 129 & 142 & 156 & 225 & 312 & 275 & 2537 \\
Hulu & $(11)$ & $(8)$ & $(11)$ & $(11)$ & $(9)$ & $(6)$ & $(6)$ & $(7)$ & $(7)$ & $(9)$ & $(12)$ & $(11)$ & $(108)$ \\
& 316 & 204 & 288 & 323 & 187 & 167 & 168 & 206 & 239 & 271 & 330 & 348 & 3047 \\
Kampar & $(15)$ & $(10)$ & $(13)$ & $(13)$ & $(10)$ & $(8)$ & $(8)$ & $(9)$ & $(10)$ & $(13)$ & $(15)$ & $(16)$ & $(140)$ \\
& 249 & 206 & 277 & 283 & 193 & 154 & 122 & 144 & 194 & 258 & 290 & 280 & 2650 \\
Kuantan & $(13)$ & $(10)$ & $(12)$ & $(12)$ & $(9)$ & $(7)$ & $(6)$ & $(7)$ & $(8)$ & $(11)$ & $(12)$ & $(13)$ & $(120)$ \\
Singingi & 200 & 110 & 227 & 241 & 167 & 132 & 138 & 147 & 201 & 212 & 239 & 270 & 2284 \\
Pelalawan & $(12)$ & $(7)$ & $(12)$ & $(13)$ & $(9)$ & $(7)$ & $(8)$ & $(8)$ & $(9)$ & $(12)$ & $(13)$ & $(14)$ & $(115)$ \\
& 158 & 112 & 186 & 199 & 172 & 110 & 99 & 134 & 150 & 183 & 214 & 215 & 1932 \\
Siak & $(11)$ & $(8)$ & $(11)$ & $(12)$ & $(11)$ & $(8)$ & $(8)$ & $(9)$ & $(9)$ & $(12)$ & $(14)$ & $(14)$ & $(127)$ \\
& 171 & 125 & 208 & 219 & 184 & 140 & 146 & 170 & 222 & 233 & 261 & 238 & 2315 \\
Bengkalis & $(11)$ & $(8)$ & $(12)$ & $(13)$ & $(11)$ & $(8)$ & $(9)$ & $(10)$ & $(11)$ & $(13)$ & $(14)$ & $(14)$ & $(134)$ \\
& 154 & 103 & 173 & 193 & 149 & 115 & 119 & 135 & 216 & 200 & 236 & 228 & 2021 \\
Rokan & $(10)$ & $(7)$ & $(10)$ & $(11)$ & $(10)$ & $(8)$ & $(9)$ & $(10)$ & $(12)$ & $(13)$ & $(14)$ & $(13)$ & $(127)$ \\
Hilir & 251 & 181 & 238 & 256 & 175 & 125 & 121 & 154 & 209 & 252 & 324 & 318 & 2604 \\
Rokan & $(13)$ & $(9)$ & $(12)$ & $(11)$ & $(8)$ & $(7)$ & $(7)$ & $(8)$ & $(10)$ & $(12)$ & $(13)$ & $(15)$ & $(125)$ \\
Hulu & 171 & 125 & 208 & 219 & 184 & 140 & 146 & 170 & 222 & 233 & 261 & 238 & 2315 \\
Kepulauan & $(11)$ & $(8)$ & $(12)$ & $(13)$ & $(11)$ & $(8)$ & $(9)$ & $(10)$ & $(11)$ & $(13)$ & $(14)$ & $(14)$ & $(134)$ \\
Meranti & & & & & & & & & & & &
\end{tabular}

Untuk ekosistem gogo, air yang tersimpan di pori-pori tanah masih bisa dimanfaatkan akar tanaman, sehingga evapotranspirasi pada padi gogo diduga sebesar 90-200 mm/bulan atau curah hujan sebesar 146$293 \mathrm{~mm} /$ bulan sudah cukup. Namun yang perlu menjadi perhatian adalah waktu tanam, dimana merupakan masalah pada keadaan tadah hujan karena keragaman dari awal musim hujan. Biasanya, penerapan waktu tanam didasarkan pada curah hujan rata-rata per dekade (10 harian). Baradas (1984 dalam Badan Penelitian 
dan Pengembangan Provinsi Riau, 2012) menyarankan penanaman padi gogo dimulai bila curah hujan dalam dekade awal dan dekade berikutnya telah mencapai $50 \mathrm{~mm}$.

\section{Hasil-Hasil Penelitian dalam Penanganan Kendala Lahan Marginal untuk Budidaya Padi Gogo}

Keinginan untuk memanfaatkan lahan marginal kering yang tidur untuk pertanian, khususnya untuk padi gogo perlu perhatian dan pengelolaan dengan cermat sesuai dengan watak dan ciri tanah tersebut. Rusman dkk., (2010) mengatakan lahan marginal (sub optimal) mempunyai tingkat kesuburan rendah dan bila dimanfaatkan untuk berusahatani, apabila tanpa ada masukan yang tinggi maka hasilnya akan rendah, bahkan petani bisa merugi, sehingga lahan ini sering ditelantarkan dan hanya didominasi oleh vegetasi alang-alang. Budidaya padi gogo di Provinsi Riau umumnya diusahakan pada lahan-lahan kering jenis Ultisol dan Inceptisol. Faktor penting klasik dan sangat mempengaruhi budidaya padi gogo di tanah tersebut adalah kekeringan. Menurut Yang et al. (2010), kekeringan adalah cekaman lingkungan yang paling penting dalam mempengaruhi pertanian secara luas. Beberapa varietas padi gogo lokal telah dibudidayakan masyarakat secara turun-temurun, seperti Varietas Kalpatali dan Si Kuning (berasal dari Rokan Hulu); Varietas Santan dan Pulau Petai (dari Kabupaten Kuantan Singingi); dan varietas Dara, Kulit Manis, Padi 4 Bulan, dan Ketitir (dari Bengkalis) Varietas-varietas lokal ini berpotensi hasil rendah, namun toleran terhadap kekeringan dan $\mathrm{pH}$ rendah. Umumnya pembudidayaan tanaman padi gogo oleh petani di Riau menggunakan benih dari hasil panen pertanaman musim sebelumnya, ditanam masyarakat secara turun temurun dan jarang dipupuk. Salah satu potensi yang perlu dikaji adalah seberapa besar respon tanaman padi gogo varietas lokal tersebut terhadap pupuk $\mathrm{N}, \mathrm{P}$ dan $\mathrm{K}$ dengan harapan dapat ditingkatkan hasil panennya. Menurut Departemen Pertanian (2013) takaran pupuk yang dianjurkan untuk padi gogo yaitu Urea $150 \mathrm{~kg}$, SP-36 135 $\mathrm{kg}$ dan $\mathrm{KCl} 60 \mathrm{~kg} / \mathrm{ha}$. Ternyata pemberian pupuk N, P, dan K kurang direspon oleh padi gogo varietas lokal dan direspon oleh varietas unggul. Respon beberapa varietas lokal terhadap pemupukan disajikan pada Tabel 5 dan 6.

Tabel 5. Rerata berat gabah/polybag (g) beberapa varietas padi gogo lokal dari Kunsing akibat pemberian pupuk N, P, K di tanah Inceptisol

\begin{tabular}{lcccc}
\hline \multirow{2}{*}{$\begin{array}{c}\text { Trea, SP-36, KCl } \\
\text { (g/polybag) }\end{array}$} & \multicolumn{3}{c}{ Berat Gabah/polybag (g) Varietas } & \multirow{2}{*}{ Rerata } \\
\cline { 2 - 4 } & Santan & Pulau Petai & Inpago 5 & \\
\hline Tanpa pupuk N, P, K & $5.91 \mathrm{a}$ & $6.11 \mathrm{a}$ & $5.86 \mathrm{a}$ & $5.962 \mathrm{a}$ \\
Diberi 1/2 N, P, K & $4.35 \mathrm{a}$ & $6.77 \mathrm{a}$ & $5.59 \mathrm{a}$ & $5.572 \mathrm{a}$ \\
Diberi 1 N, P, K & $7.29 \mathrm{a}$ & $8.96 \mathrm{a}$ & $9.18 \mathrm{a}$ & $8.479 \mathrm{a}$ \\
Diberi 1 1 $1 / 2 \mathrm{~N}, \mathrm{P}, \mathrm{K}$ & $3.02 \mathrm{a}$ & $5.40 \mathrm{a}$ & $8.65 \mathrm{a}$ & $5.691 \mathrm{a}$ \\
\hline Rerata & $5.144 \mathrm{~A}$ & $6.813 \mathrm{~A}$ & $7.322 \mathrm{~A}$ & \\
\hline
\end{tabular}

Sumber: Idwar dkk (2015)

Tabel 6. Rata-rata berat gabah per rumpun (g) beberapa varietas padi gogo lokal dari Bengkalis yang diaplikasikan beberapa takaran pupuk Urea, SP-36 dan $\mathrm{KCl}$ di tanah Inceptisol

\begin{tabular}{|c|c|c|c|c|}
\hline \multirow{2}{*}{ Takaran N, P dan K (g/polybag) } & \multicolumn{3}{|c|}{ Rata-rata berat gabah per rumpun (g) } & \multirow{2}{*}{ Rata-rata } \\
\hline & Dara & Kulit Manis & Inpago 5 & \\
\hline Tanpa N, P dan K & $18.69 \mathrm{bcd}$ & $16.46 \mathrm{~cd}$ & $18.65 \mathrm{bcd}$ & $17.93 \mathrm{c}$ \\
\hline Urea 0,38, SP-36 0,34, $\mathrm{KCl} 0,15$ & $21.88 \mathrm{bc}$ & $16.87 \mathrm{~cd}$ & $20.11 \mathrm{bc}$ & $19.62 \mathrm{~b}$ \\
\hline Urea $0,75, \mathrm{SP}-360,68, \mathrm{KCl} 0,3$ & $20.30 \mathrm{bc}$ & $15.24 \mathrm{~cd}$ & $30.20 \mathrm{a}$ & $21.91 \mathrm{~b}$ \\
\hline Urea 1,12, SP-36 1,01, KCl 0,45 & $20.17 \mathrm{bc}$ & $18.03 \mathrm{bcd}$ & $30.62 \mathrm{a}$ & $22.93 \mathrm{a}$ \\
\hline Rata-rata & $20.24 \mathrm{a}$ & $16.00 \mathrm{c}$ & $24.89 \mathrm{a}$ & \\
\hline
\end{tabular}

Sumber: Norkhalimah (2015)

Di Riau telah dikenal beberapa varietas lokal dan unggul seperti Santan, Kalpatali dan Sikuning (varietas lokal) dan sedang varietas unggul seperti Situ Bagendit, Situ Patenggang, Inpago 5 dan Inpago 8 yang memiliki keunggulan hasil 4,0 - 5,20 ton/ha, umur tanaman 110 - 120 hari dan toleran terhadap cekaman abiotik (kekeringan). Dengan demikian seleksi varietas tanaman padi gogo unggul nasional dan lokal ini terhadap tegangan aair tanah sangat berguna untuk mendapatkan varietas yang adaptif terhadap cengkraman kekeringan. Hasil penelitian rumah kaca tentang pengaruh tegangan air tanah Ultisol tehadap padi gogo lokal dan unggul, ternyata varietas unggul Situ Bagendit lebih tahan kekeringan dan mampu menghasilkan gabah yang tetap tinggi. Untuk jelas disajikan pada Tabel 7 dan 8 . 
Tabel 7. Pengaruh Tegangan Air Tanah Ultisol Terhadap Berat Gabah Kering Giling per Rumpun Beberapa Tanaman Padi Gogo Varietas Lokal

\begin{tabular}{|c|c|c|c|c|}
\hline \multirow{2}{*}{$\begin{array}{l}\text { Varietas } \\
\text { Padi Gogo }\end{array}$} & \multicolumn{3}{|c|}{ Tegangan Air Tanah } & \multirow{2}{*}{$\begin{array}{c}\text { Rata-Rata } \\
\text { Varietas }\end{array}$} \\
\hline & pF $1-1,97$ & $\mathrm{pF} 2,29-2,54$ & $\mathrm{pF} 2,70-3$ & \\
\hline Santan & $7,13 \mathrm{a}$ & $5,25 \mathrm{~b}$ & $2,63 \mathrm{~d}$ & $5,03 \mathrm{a}$ \\
\hline Kalpatali & $6,86 \mathrm{a}$ & $4,45 \mathrm{c}$ & $2,49 \mathrm{~d}$ & $4,60 \mathrm{a}$ \\
\hline Si Kuning & $7,04 \mathrm{a}$ & $5,01 \mathrm{bc}$ & $2,47 \mathrm{~d}$ & $4,84 \mathrm{a}$ \\
\hline $\begin{array}{c}\text { Rata-Rata } \\
\text { Tegangan Air Tanah }\end{array}$ & $7,01 \mathrm{a}$ & $4,90 \mathrm{~b}$ & $2,53 \mathrm{c}$ & \\
\hline
\end{tabular}

Sumber: Idwar dkk., 2017

Tabel 8. Rata-rata berat gabah kering giling per rumpun (g) beberapa varietas padi gogo Unggul dengan perlakuan tegangan air tanah Ultisol

\begin{tabular}{cllll}
\hline \multirow{2}{*}{$\begin{array}{c}\text { Tegangan Air Tanah } \\
(\mathrm{pF})\end{array}$} & \multicolumn{3}{c}{ Varietas Padi Gogo } & Rata - Rata Tegangan \\
\cline { 2 - 4 } Air Tanah
\end{tabular}

Sumber: Rasyid, 2017

Selanjutnya untuk mengoptimalkan budidaya padi gogo varietas unggul di lahan kering perlu diberi bahan amelioran, seperti kapur, bahan organik dan batuan fosfat alam (BFA). Penggunaan varietas unggul dengan pemberian amelioran diharapkan dapat menjadi teknologi paling murah dan efisien untuk mengoptimalkan hasil padi gogo di lahan kering Ultisol. Hasil penelitian uji beberapa padi gogo varietas unggul dengan pemberian amelioran mendapatkan Varietas Inpago 8 dan Situ Patenggang termasuk varietas produktif untuk dikembangkan pada lahan marginal Ultisol, sepeti yang disajikan pada Tabel 9.

Tabel 9. Berat gabah kering beberapa padi gogo varietas unggul akibat pemberian campuran amelioran di tanah Ultisol

\begin{tabular}{|c|c|c|c|c|}
\hline \multirow{2}{*}{ Campuran Amelioran } & \multicolumn{3}{|c|}{ Rata-rata Berat gabah kering (g) Varietas } & \multirow{2}{*}{ Rata-rata } \\
\hline & Inpago 8 & Situ Patenggang & Situ Bagendit & \\
\hline -Tanpa campuran amelioran & $12,39 \mathrm{bcde}$ & $10,59 \mathrm{cde}$ & $8,77 \mathrm{~cd}$ & $10,59 b c$ \\
\hline $\begin{array}{l}\text { - Kapur } 24,99 \mathrm{~g}+\text { pupuk hijau krinyuh } 12,49 \\
\text { g/polybag }\end{array}$ & $13,89 \mathrm{bcd}$ & $15,00 \mathrm{bc}$ & $11,71 \mathrm{bcd}$ & $13,54 \mathrm{~b}$ \\
\hline - Kapur $24,99 \mathrm{~g}+$ BFA $12,49 \mathrm{~g} /$ polybag & $10,75 \mathrm{~cd}$ & $10,19 \mathrm{cde}$ & $6,97 \mathrm{~d}$ & $9,31 \mathrm{c}$ \\
\hline $\begin{array}{l}\text { - Pupuk hijau krinyuh } 12,49 \mathrm{~g}+\text { BFA } 12,49 \\
\text { g/polybag }\end{array}$ & $24,19 \mathrm{a}$ & $18,47 \mathrm{ab}$ & $13,70 \mathrm{bcd}$ & $18,79 \mathrm{a}$ \\
\hline $\begin{array}{l}\text { - Kapur } 24,99 \mathrm{~g}+\text { pupuk hijau krinyuh } \\
\text { 12,49 g + BFA 12,49 g /polybag }\end{array}$ & $10,67 \mathrm{~cd}$ & $15,75 \mathrm{bc}$ & $9,43 \mathrm{~cd}$ & $11,95 b c$ \\
\hline Rata-rata & $14,38 \mathrm{a}$ & $14,00 \mathrm{a}$ & $10,18 \mathrm{~b}$ & \\
\hline
\end{tabular}

Sumber: Idwar dkk., 2016

Tabel10.Pengaruh kompos TKKS dan cara pengolahan tanah terhadap berat gabah kering giling/plot padi gogo varietas Situ Bagendit di tanah Inceptisol

\begin{tabular}{|c|c|c|c|c|}
\hline \multirow{2}{*}{ Kompos TKKS (ton/ha) } & \multicolumn{3}{|c|}{ Pengolahan Tanah } & \multirow{2}{*}{ Rataan } \\
\hline & TOT & OTM & OTS & \\
\hline & ................... & ...... g/plot ... & 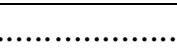 & \\
\hline 0 & $158,52 \mathrm{e}$ & $195,80 \mathrm{e}$ & 220,12 de & $191,48 \mathrm{~b}$ \\
\hline 2,5 & $187,95 \mathrm{e}$ & 251,22 cde & $417,04 \mathrm{bc}$ & $285,40 \mathrm{~b}$ \\
\hline 5 & 299,42 cde & $411,90 \mathrm{bcd}$ & $631,48 \mathrm{a}$ & $447,60 \mathrm{a}$ \\
\hline 7,5 & 344,90 cde & $538,65 \mathrm{ab}$ & $679,04 \mathrm{a}$ & $520,87 \mathrm{a}$ \\
\hline Rataan & $247,70 \mathrm{c}$ & $349,39 \mathrm{~b}$ & $486,92 \mathrm{a}$ & \\
\hline
\end{tabular}

Sumber: Silalahi dan Wawan (2017)

Sebenarnya upaya peningkatan produksi tanaman padi gogo yang paling tepat untuk diaplikasikan di Provinsi Riau yaitu pemanfaatan lahan kosong (gawangan mati) di areal perkebunan kelapa sawit belum menghasilkan. Badan Pusat Statistik Provinsi Riau (2015) menunjukkan bahwa Provinsi Riau memiliki 
perkebunan kelapa sawit seluas 2.372.402 ha tahun 2013, sebesar 14,09 \% (seluas 334.271,44 ha) merupakan lahan tanaman belum menghasilkan (TBM) yang bisa dimanfaatkan untuk pertanaman padi gogo. Hasil penelitian pemberian kompos TKKS dan cara pengolahan tanah untuk tanaman padi gogo varietas Situ Bagendit di tanah Inceptisol disajikan pada Tabel 10.

Tabel 10 menunjukkan bahwa penanaman padi gogo di bawah tegakan kelapa sawit belum menghasilkan (TBM) dengan jenis tanah Inceptisol diperlukan pengolahan tanah sempurna dan pemberian kompos TKKS. Pemberian 5 ton/ha kompos TKKS dan diolah tanah secara sempurna menghasilkan berat gabah kering giling padi gogo varietas Situ Bagendit cukup besar $631,48 \mathrm{~g} / 6 \mathrm{~m} 2$ (1,05 ton/ha) walaupun pemberian kompos TKKS 7,5 ton/ha dengan olah tanah sempurna lebih tinggi yaitu sebesar 679,04 g/6m2 (1,13 ton/ha).

Pada prinsipnya, olah tanah sempurna bertujuan untuk menciptakan kondisi tanah yang lebih baik untuk pertumbuhan tanaman padi gogo. Namun, apabila dilakukan secara terus menerus dapat berdampak buruk bagi kondisi tanah dan perkembangan perakaran kelapa sawit. Untuk menghindari resiko tersebut maka pengolahan tanah minimum (OTM) dan penambahan bahan organik sangat dianjurkan untuk memperbaiki sifat fisik, biologi dan kimia tanah. Dari hasil penelitian di lahan yang sama (Inceptisol), ternyata pemberian pupuk kandang ayam 10 ton/ha lebih baik dibanding dengan kompos TKKS 10 ton/ha. Untuk jelasnya disajikan pada Tabel 11.

Tabel 11.Berat gabah kering giling (g) tanaman padi gogo terhadap pemberian pupuk organik di tanah Inceptisol di gawangan kebun kelapa sawit belum menghasilkan

\begin{tabular}{|c|c|c|c|c|}
\hline \multirow{2}{*}{$\begin{array}{l}\text { Pupuk Organik } \\
\text { (ton/ha) }\end{array}$} & \multicolumn{3}{|c|}{ Varietas Padi Gogo } & \multirow{2}{*}{ Rataan } \\
\hline & Inpago 8 & Situ Bagendit & Inpago 9 & \\
\hline & & $\mathrm{g} / \mathrm{plot}$ & & \\
\hline Tanpa Perlakuan & $541,00 \mathrm{e}$ & $578,33 \mathrm{de}$ & $542,00 \mathrm{e}$ & $553,78 b$ \\
\hline Kompos TKKS 10 ton & $607,00 \mathrm{~cd}$ & $683,67 \mathrm{~b}$ & $594,67 \mathrm{~cd}$ & $646,78 \mathrm{a}$ \\
\hline Pukan Ayam 10 ton & $637,33 \mathrm{~cd}$ & $738,67 \mathrm{a}$ & $610,00 \mathrm{~cd}$ & $662,22 \mathrm{a}$ \\
\hline Kirinyuh 10 ton & $609,00 \mathrm{~cd}$ & $682,67 \mathrm{~b}$ & $615,00 \mathrm{~cd}$ & $635,56 \mathrm{a}$ \\
\hline Rataan & $598,58 \mathrm{~b}$ & $670,83 \mathrm{a}$ & $590,41 b$ & \\
\hline
\end{tabular}

Sumber: Masri (2017)

Dari hasil penelitian-penelitian di atas, ternyata pemanfaatan lahan marginal kering jenis tanah Inceptisol untuk budidaya padi gogo unggul varietas Situ Bagendit lebih optimal hasil berat gabah kering giling yaitu $738,67 \mathrm{~g} / 2,25 \mathrm{~m} 2$ (4,58 ton/ha) apabila dibarengi dengan pupuk kandang ayam 10 ton/ha, sedangkan dengan pemberian kompos TKKS 10 ton/ha menghasikan 683,67 g/2,25m2 (4,24 ton/ha) dan pemberian kirinyuh 10 ton/ha menghasilkan 682,67 g/2,25 m2 (4,23 ton/ha). Sedangkan pemanfaatan lahan marginal kering jenis tanah Ultisol untuk budidaya padi gogo Inpago 8 dan Situ Patenggang lebih produktif apabila diberi pupuk organik kirinyuh dan batuan fosfat alam (BFA).

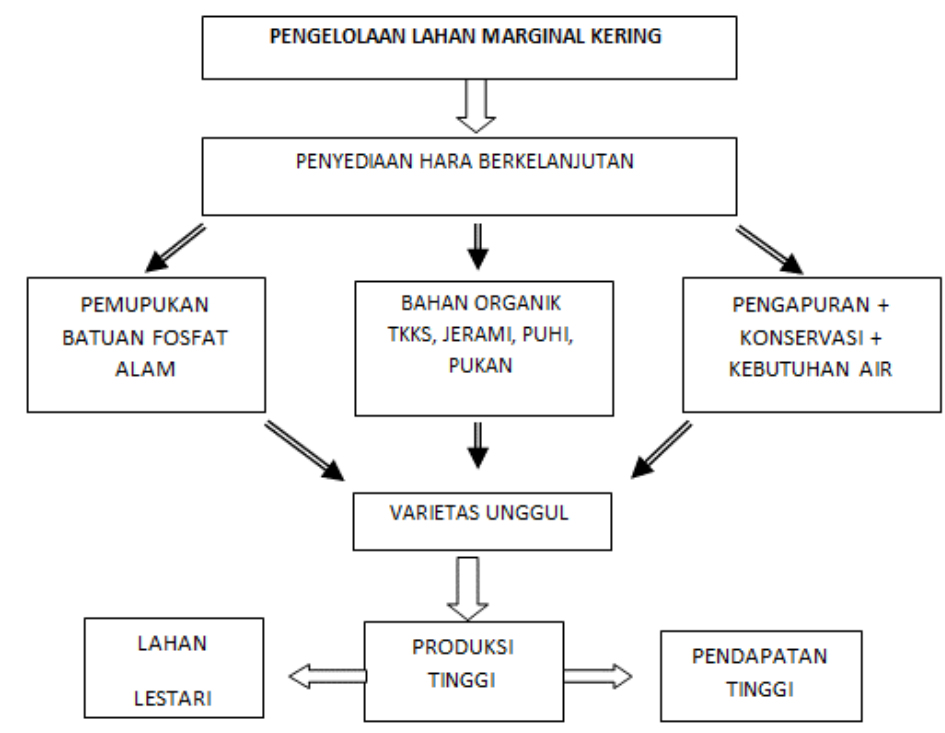

Gambar 2. Target yang harus dicapai dalam pemanfaatan lahan marginal kering 
Sebagai penutup, tanah yang dapat dijadikan untuk tanaman pangan, khususnya untuk budidaya padi gogo cukup tersedia di Riau. Walaupun lahan marginal kering yang didominasi jenis tanah Inceptisol dan Ultisol memiliki berbagai kendala, namun tidak berarti tanah itu tidak bisa dibentuk menjadi produktif. Memanfaatkan dan merawat adalah kiat kesuksesan mengelola lahan marginal kering, karena keragaan tanaman merupakan fungsi dari faktor-faktor genetika, sumberdaya alam dan managemen. Masing-masing faktor dapat direkayasa dengan masukan teknologi.

Selain itu, agar lahan yang telah diusahakan untuk budidaya padi gogo dan diyakini mampu mendukung ketersediaan beras di Riau, maka baik pemerintah pusat maupun daerah konsisten menerapkan UU Nomor 41 Tahun 2009 tentang Perlindungan Lahan Pertanian Pangan Berkelanjutan. Lambat tapi pasti ketahanan pangan (food security) dan keamanan lahan (land Security) akan terwujud.

Sebagai ilustrasi, gambar di bawah merupakan target yang harus dicapai dalam optimalisasi pemanfaatan lahan marginal kering.

\section{KESIMPULAN}

1. Lahan marginal kering yang dapat dijadikan untuk budidaya padi gogo cukup tersedia dan memiliki peluang pengembangan seluas \pm 306.507 ha di Riau, didominasi oleh jenis tanah Ultisol dan Inceptisol, yang memiliki berbagai kendala sepeti ketersedian air yang kurang, kesuburan rendah dan bereaksi masam.

2. Optimalisasi pemanfaatan lahan marginal kering untuk budidaya padi gogo masih bisa dibentuk menjadi produktif dengan meningkatkan ketersediaan air tanah, pengolahan lahan, dan dengan pemanfaatan sumber daya alam yang tersedia seperti pupuk kandang, tandan kosong kelapa sawit, dan lain lain.

3. Ketersedian air yang cukup selama pertumbuhan tanaman padi gogo baik untuk varietas unggul maupun lokal merupakan faktor utama dalam menentukan produktifitas lahan.

4. Padi gogo unggul Varietas Inpago 8 dan Situ Patenggang termasuk varietas produktif untuk dikembangkan pada lahan marginal Ultisol sedang pada tanah Inceptisol di anjurkan penggunaan varietas Situ Bagendit.

5. Pemanfaatan lahan gawangan mati tanaman kelapa sawit belum menghasilkan (TBM) untuk bududaya padi gogo menghendaki pengolahan tanah sempurna (OTS). Untuk menjaga dari kerusakan lahan maka pengolahan tanah minimum (OTM) dan penambahan bahan organik sangat dianjurkan sekali.

6. Produktifitas padi gogo varietas Situ Bagendit optimal yaitu $738,67 \mathrm{~g} / 2,25 \mathrm{~m} 2$ (4,58 ton/ha) apabila diberi pupuk kandang ayam 10 ton/ha sedang diberi kompos TKKS 10 ton/ha hasilnya 683,67 g/2,25m2 (4,24 ton/ha) di gawangan kebun kelapa sawit belum menghasilkan.

Upaya optimalisasi pemanfaatan lahan marginal kering untuk budidaya padi gogo menjadi tumpuan masa depan dalam memenuhi kebutuhan bahan pangan, terutama beras. Keberlangsungan budidaya padi gogo dan lahannya tetap lestari perlu ditunjang dengan ketersediaan sarana benih varietas unggul, pupuk dan prasara pendukung ketersediaan air serta komitmen pemerintah pusat maupun daerah dalam menerapkan UU Nomor 41 Tahun 2009 tentang Perlindungan Lahan Pertanian Pangan Berkelanjutan.

\section{DAFTAR PUSTAKA}

Badan Penelitian dan Pengembangan Provinsi Riau. 2012. Studi Dinamika Air Tanah untuk Pengembangan Padi Gogo Sebagai Alternatif Peningkatan IP dalam Rangka Mensukseskan OPRM.

Badan Pusat Statistik. 2006. Riau Dalam Angka. Pekanbaru: BPS-Bappeda Provinsi Riau.

Departemen Pertanian. 2013. Penanaman dan Pemupukan Padi Gogo Tanpa Olah Tanah. http://cybex.deptan.go.id/penyuluhan/penanaman-dan-pemupukan-padi-gogo-tanpa-olah-tanah Diakses pada tanggal 22 November 2014.

Dinas Tanaman Pangan dan Hortikultura Provinsi Riau. 2011. Statistik Pertanian Tanaman Pangan dan Hortikultura Provinsi Riau. Pekanbaru.

Hakim, L. 2014. Padi Gogo Cocok untuk Lahan Kering. Disampaikan oleh Lembaga lmu Pengetahuan Indonesia (LIPI).

Idwar, Armaini, Islan, dan J. Stephanie. 2016. Pengaruh Campuran Amelioran (Kapur Kalsit, Pupuk Hijau Krinyuh Dan Batuan Fosfat Alam) terhadap Beberapa Varietas Padi Gogo (Oryza Sativa L.) di Tanah Ultisol. Makalah 
Seminar Nasional \& Rapat Tahunan Dekan Bidang Ilmu Pertanian BKS-PTN Barat Tanggal 5-6 Agustus 2016 di Banda Aceh.

Idwar, S. Yoseva, dan R. Fitri, 2015. Respon Beberapa Varietas Tanaman Padi Gogo (Oryzasativa L.) terhadap Pemberian Pupuk N, P Dan K di Tanah Inceptisol. Makalah Seminar Nasional \& Rapat Tahunan Dekan Bidang Ilmu Pertanian BKS-PTN Barat Tanggal 20-21 Agustus 2015 di Palangka Raya (Kalimantan Tengah).

Rasyid, M. 2017. Respon Beberapa Varietas Padi Gogo (Oryza Satival.) Unggul Pada Kondisi Tegangan Air yang Berbeda di Media Tanah Ultisol. Skripsi Fakultas Pertanian Unri (Tidak dipublikasikan).

Masri, N. 2017. Pemberian Berbagai Pupuk Organik terhadap Pertumbuhan dan Produksi Beberapa Varietas Padi Gogo yang ditanam Diantara Tanaman Kelapa Sawit Belum Menghasilkan. Skripsi Fakultas Pertanian Unri (Tidak dipublikasikan).

Rusman, B., Aprisal, M. Kasim, I. Dwipa, dan Refdinal. 2010. Model Usahatani Konservasi di Lahan Marginal dalam Meningkatkan Ketahanan Pangan Keluarga Petani Miskin Pedesaan di Daerah Tangkapan Air Singkarak. Prosiding Semirata BidangIlmu-Ilmu Pertanian BKS-PTN Wilayah Barat Tahun 2010. Hal 557-564.

Silalahi, J.D., dan Wawan. 2017. Pengaruh Kompos Tandan Kosong Kelapa Sawit dan Cara Pengolahan Tanah Terhadap Pertumbuhan dan Produksi Padi Gogo (Oryza Sativa L.) di Antara Tanaman Kelapa Sawit Belum Menghasilkan. JOM FAPERTA Universitas Riau 4(1): 1-15.

Soepardi, G. 1990. Mengelola Lahan yang Tanahnya Berkendala Reaksi Masam. Seminar Nasional PLANTAGAMA, Tanggal 27 Oktober 1990. Yogyakarta.

Yang, S., B. Vanderbeld, J. Wan, and Y. Huang. 2010. Narrowing Down The Targets: Towards Successful Genetic Engineering of Drought-Tolerant Crops. Performance Plants Inc., 700 Gardiners Road, Kingston, Ontario, K7M 3X9, Canada.

Norkhalimah, S. 2015. Respon Beberapa Varietas Padi Gogo Terhadap Pemupukan N, P Dan K di Tanah Inceptisol. Skripsi Fakultas Pertanian Unri (Tidak dipublikasikan).

Undang-Undang Nomor 41 Tahun 2009 Tentang Perlindungan Lahan Pertanian Pangan Berkelanjutan. 